\title{
Study of Heavy Metals contamination in Mangrove Sediments of the Red Sea Coast of Yemen from Al-Salif to Bab-el-Mandeb
} Strait

\section{Al Hagibi HA*, Al-Selwi KM, Nagi HM and Al-Shwafi NA \\ Department of Earth and Environmental Sciences, Sana'a University, Yemen}

*Corresponding author: Hagib A Al-Hagibi, Department of Earth and Environmental Sciences, Faculty of Science, Sana'a University, Yemen, Tel: 00967777322298; Email: Hagib_2002@Hotmail.com

\section{Research Article}

Volume 2 Issue 1

Received Date: January 28, 2018

Published Date: February 20, 2018

DOI: $10.23880 /$ jenr-16000121

\section{Abstract}

This research aimed to estimate the concentration of $\mathrm{Pb}, \mathrm{Cd}, \mathrm{Cr}, \mathrm{Ni}, \mathrm{Co}, \mathrm{Cu}, \mathrm{Zn}, \mathrm{Mn}, \mathrm{Mg}$ and $\mathrm{Fe}$ in the sediments of mangrove habitats located in the Yemeni from Al-Salif to Bab-el-Mandeb Strait. Samples were collected seasonally at five locations: Al-Salif, Al-Urj, Al-Hodeidah, Yakhtol and Ghorairah, during the months of January, April, August and October 2013, which are chosen to represent the four seasons of a full year. Atomic Absorption Spectroscopy techniques were used to determine heavy metals concentration in the samples, which extracted using Acid digestion methods. The results showed that Heavy metals concentration $(\mu \mathrm{g} / \mathrm{g})$ in mangrove sediments were in the following order: Fe (8,432.015,255.2) > Mg (915.2-2,066.0) > Mn (195.8-528.0) > Zn (27.5-57.2) > Cu (12.3-40.7) > Ni (15.5-34.7) > Cr (15.3-35.6) > $\mathrm{Pb}(6.2-16.6)>\mathrm{Co}(6.2-15.8)>\mathrm{Cd}$ (ND-0.57). The levels of these metals in mangrove sediments were comparable with corresponding in other less polluted area of the world. These metals does not exceed Threshold Effect Level (TEL) and Probable Effect Level (PEL) guidelines, except $\mathrm{Cu}$ and Ni, which indicated may be cause low harmful biological effects as proposed by CCME. $\mathrm{Cu}, \mathrm{Ni}, \mathrm{Cd}$ and $\mathrm{Mg}$ showed low to moderate polluted status according to USEPA. Relatively high metals concentration at Al-Hodeidah could be due to increasing anthropogenic activities in the vicinity of this site, whereas at Ghorairah may be attributed to the potential contaminants that carried by water currents coming from the Gulf of Aden. Al-Salif and Yakhtol showed no polluted by the studied metals. This might be due to limited influence of anthropogenic activities at these two sites. Elevated metals level during spring and summer may be associated with increasing biological activities, land run off and rainfall during these seasons. Continuous monitoring of these metals in mangrove habitats is recommended to avoid being overcome permissible limits. These findings provide actual heavy metals levels in mangrove sediments being important in designing the long-term management and conservation policies of mangrove ecosystems. In addition, it could represent a database for the future research investigations.

Keywords: Heavy Metals; Mangrove; Sediments; Red Sea; Yemen 


\section{Journal of Ecology \& Natural Resources}

\section{Introduction}

Heavy metals are one of the most serious pollutants in natural environment due to their toxicity, persistence and bioaccumulation problems. These elements are not biodegradable and then have a long residence time within the food chains and environment $[1,2]$. Mangroves form a unique group of intertidal ecosystems that dominate over large extents of shorelines and estuaries in tropical and subtropical regions [3,4]. Currently, mangroves are increasingly threatened due to anthropogenic chemicals sourced from uncontrolled agricultural runoff, urban and industrial effluent and wastewaters, as well as with urbanization and population growth [5,6]. Mangrove ecosystems are among the most productive and biologically important ecosystems of the world because they provide important and unique ecosystem goods and services to human society and coastal and marine systems [7]. Economically, they Play a very important role in fishing, agriculture, reed production, husbandry, ecological tourism, educational and scientific researches, and protecting coastlines from the devastating effects of erosion $[8,9]$. They may act as a sink or a source of heavy metals in coastal environments because of their variable physical and chemical properties [10,11]. The high capability of mangrove to absorb and store heavy metals in its sediments, it is because of the physicochemical properties of these sediments [6,12]. Mangrove sediments are mainly in anaerobic conditions and have high amounts of organic matter. Thus, their sediments are a good indicator of heavy metal concentration $[13,14]$. Mangroves are one of the important habitats in the Red Sea coast of Yemen and are dominated by Avicennia marina. In the Red Sea coast of Yemen, there are several studies on heavy metal contaminations in coastal sediments but little is known about heavy metals in mangrove sediments.

The aim of the present study is to provide information on the seasonal concentrations of ten heavy metals $(\mathrm{Pb}$, $\mathrm{Cd}, \mathrm{Cr}, \mathrm{Ni}, \mathrm{Co}, \mathrm{Cu}, \mathrm{Zn}, \mathrm{Mn}, \mathrm{Mg}$ and $\mathrm{Fe}$ ) in mangrove sediments of the Red Sea Coast of Yemen from Al-Salif to Bab-el-Mandeb Strait. The measurement of the seasonal variation in heavy metal concentrations and distribution in the sediments would give us a better understanding of the inputs of the accumulated metals in mangrove ecosystems and thus the quality of local coastal environment. The present investigation would be of a great help in monitoring the trace metals pollution in Yemen's coastal area, particularly, in mangrove ecosystem. It could be used as a baseline information for future studies with regard to this field.

\section{Materials and Methods}

\section{Study Area}

The area under investigation is lying from the south eastern part of the Red Sea in the coast of Yemen. It extends from Al-Salif which is located at latitude $15^{\circ} 12^{\prime}$ $35^{\prime \prime} \mathrm{N}$ and longitude $42^{\circ} 46^{\prime} 16^{\prime \prime} \mathrm{E}$ to Bab-el-Mandeb Strait in the south at $12^{\circ} 44^{\prime} 33^{\prime \prime} \mathrm{N}$ latitude and $43^{\circ} 28^{\prime}$ $22^{\prime \prime}$ E longitude. The distinctive areas are namely Al-Salif, Al-Urj, Al-Hodeidah, Yakhtol and Ghorairah (Figure 1). Sampling was carried out on seasonally basis during the year 2013. Samples were collected during the months of January, April, August and October 2013, which are chosen to represent the four seasons of a full year. Location of selected stations (Table 1) were determined by geographical position system GPS (Digital Garmin eTrex Vista C).

\begin{tabular}{|c|c|c|c|}
\hline \multirow{2}{*}{ Station No. } & \multirow{2}{*}{ Nearest City } & \multicolumn{2}{|c|}{ Location of Station } \\
\cline { 3 - 4 } & & Latitudes (North) & Longitudes (East) \\
\hline St-1 & Al-Salif & $15^{\circ} 12^{\prime} 35^{\prime \prime} \mathrm{N}$ & $42^{\circ} 46^{\prime} 16^{\prime \prime} \mathrm{E}$ \\
\hline St-2 & Al-Urj & $15^{\circ} 05^{\prime} 51^{\prime \prime} \mathrm{N}$ & $42^{\circ} 52^{\prime} 16^{\prime \prime} \mathrm{E}$ \\
\hline St-3 & Al-Hodeidah & $14^{\circ} 52^{\prime} 02^{\prime \prime} \mathrm{N}$ & $42^{\circ} 57^{\prime} 10^{\prime \prime} \mathrm{E}$ \\
\hline St-4 & Yakhtol & $13^{\circ} 31^{\prime} 03^{\prime \prime} \mathrm{N}$ & $45^{\prime} 55^{\prime \prime} \mathrm{E}$ \\
\hline St-5 & Ghorairah & $12^{\circ} 44^{\prime} 33^{\prime \prime} \mathrm{N}$ & $43^{\circ} 28^{\prime} 22^{\prime \prime} \mathrm{E}$ \\
\hline
\end{tabular}

Table 1: Geographical locations of the sampling stations.

\section{Samples Collection and Analysis}

A rapid survey of mangrove environment at selected sites was conducted for selection of six sub-stations, which represent the site entirely; these sub-stations were used to sampling during the four seasons.
The surface sediments samples were collected from the top $5-10 \mathrm{~cm}$ of the sediment layers from each station. Six sub-samples from each sites were collected and then mixed together to make a composite sample 


\section{Journal of Ecology \& Natural Resources}

representative of a particular site during the four seasons. labeled and immediately transported to the lab. Collected samples were transferred to polythene bags,

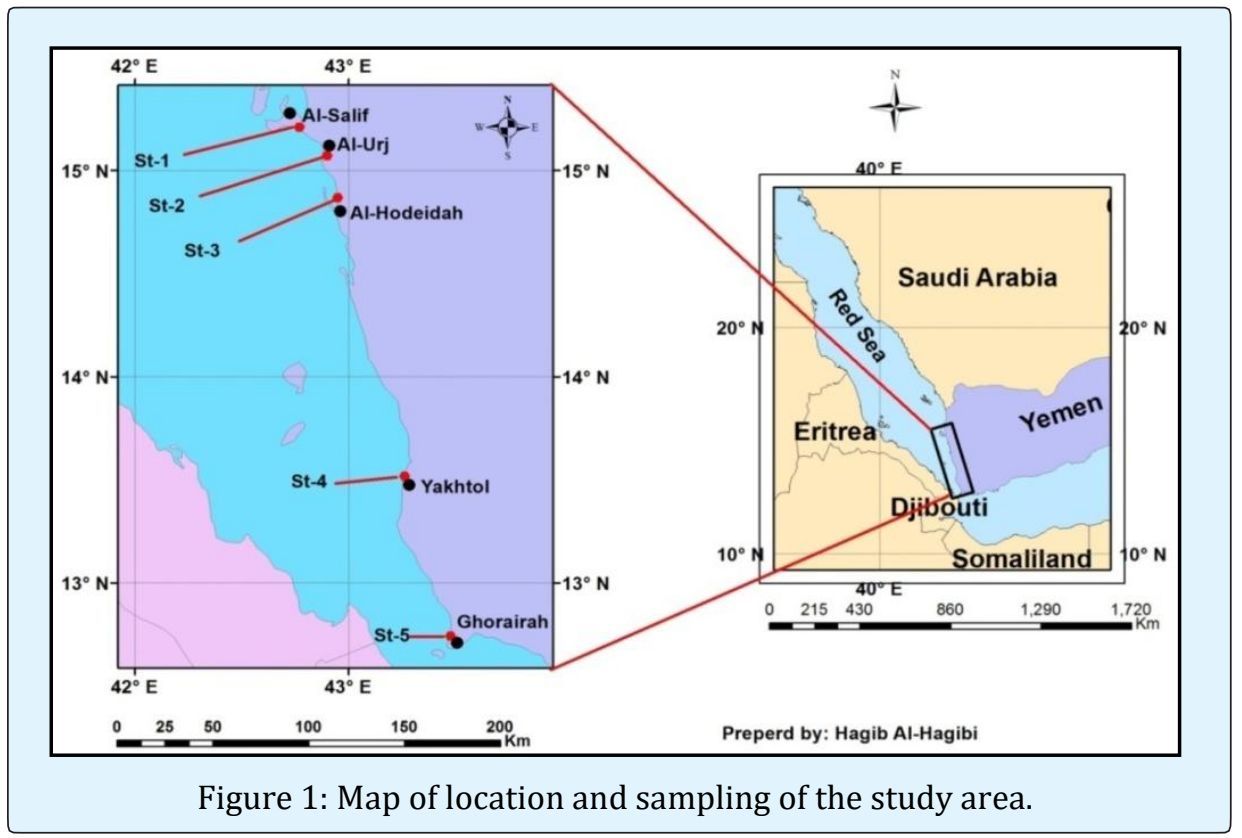

Sediment samples were gently immersed to remove the dissolved salts using deionized water. Samples then dried in an oven at $50^{\circ} \mathrm{C}$ for 24 hours. Thereafter, the sediment was sieved through a sieve of $2.0 \mathrm{~mm}$ to remove plant debris and other large particulate matter. Sediments were crushed and grind using a mortar and pestle to a homogenous grain size and sieved through a $63 \mu \mathrm{m}$ mesh sieve. Sieved powdered samples stored in polyethylene containers at a room temperature until digestion. Digestions were performed following the procedure as described by APHA [15]. For each Sieved powdered samples were homogenized in its container, exactly $3 \mathrm{~g}$ of sediments was used in the digestion process, the same procedures were used for each sample. The weighted samples were wet digested where put into $250 \mathrm{ml}$ Teflon beaker with $2.5 \mathrm{ml}$ of concentrated perchloric acid $\left(\mathrm{HClO}_{4}\right)$ and $7.5 \mathrm{ml}$ of concentrated nitric acid $\left(\mathrm{HNO}_{3}\right)$. The beaker were covered with glass plates in the fume hood and allowed to predigest overnight at room temperature. The beaker placed on a hot plate at $70{ }^{\circ} \mathrm{C}$ for two hours. The solution filtered into $250 \mathrm{ml}$ Teflon beaker using Whatman $0.45 \mu \mathrm{m}$. After cooling at room temperature, 2 $3 \mathrm{ml}$ deionized water was added to dilute each sample. Beaker reheated on a hot plate at $70^{\circ} \mathrm{C}$, and solution reduced $1-2 \mathrm{ml}$. The solution filtered into a $50 \mathrm{ml}$ volumetric flask, using Whatman $0.45 \mu \mathrm{m}$ filter paper which allows only dissolved constituents to pass though and made the final volume to a $50 \mathrm{ml}$ by deionized water.
For background correction, Blank solution was prepared for each type of sediments samples by treated in the same way of those digested of samples without samples. In addition, A certified reference material (CRM320) sample also was performed for each set of analysis using the same reagents. The digested samples, blank solution and certified reference material sample were transferred into separate plastic bottles, labeled and stored awaiting for analysis in line with the method described by Perkin-Elmer Corporation [16].

Many analytical methods including Atomic Absorption Spectrometry (AAS) for heavy metal determination in sediments require the digestion of the samples [17]. Because of its sensitivity, specificity, simplicity and precision, AAS is the most widely recommended instrument utilized in analytical procedures for heavy metal analysis [18]. The filtered samples were analyzed using Perkin Elmer AAS Model 2380, according to the manufacture's instruction. The concentration of total metals in each sample was calculated using Equation 1 [19]:

$$
\text { Econ }=(A \times B) / D
$$

(Equation 1)

Where; Econ is concentration of metal in sample $(\mu \mathrm{g} / \mathrm{g}), A$ is metal concentration in calibration curve $(\mu \mathrm{g} / \mathrm{l}), B$ is final volume of sample ( $\mathrm{ml}$ ) and $D$ is dry weight of sample (g). 


\section{Journal of Ecology \& Natural Resources}

\section{Analytical Quality Control:}

To remove any contamination, all glassware and plastic vials were washed with $10 \%$ nitric acid solution and rinsed thoroughly with distilled deionized water (DDW) and dried. Standard solutions prepared fresh daily from Merck Stick Standards or super pure quality. Blank determinations were performed for each set of analysis using the same reagents. In order to check for the quality of the method applied for the analysis of heavy metals, the accuracy of the analytical method was checked by the analysis of Certified Reference Material (CRM-320). The accuracy of analytical procedure was checked by blank solution and using certified reference material of the Community Bureau of Reference of the European Commission (Geel, Belgium); standard for heavy metals in river sediments; Certified Reference Material 320.

The percentage recovery of each metal was calculated as: Recovery \% $=($ Determined value $/$ Certified value $) \times$ 100

(Equation 2)

The accuracy of the AAS analytical procedure was investigated by calculating the percentage recovery of heavy metals. The percentage recoveries of $\mathrm{Pb}, \mathrm{Cd}, \mathrm{Cr}, \mathrm{Ni}$, $\mathrm{Co}, \mathrm{Cu}, \mathrm{Zn}, \mathrm{Mn}, \mathrm{Mg}$ and $\mathrm{Fe}$ are 96.4, 92.5, 103.5, 104.6, 106.7, 107.8, 91.9, 95.6, 102.5 and $89.19 \%$, respectively. The recovery of the selected heavy metals ranged from 89.19 to $107.8 \%$, the measurements of precision was under $\pm 11 \%$. These values were within the acceptable range of 80 to $120 \%$ expected for the metals indicating good accuracy for the analysis procedure [20]. The statistical analyses were performed by using Paleontological Statistics (PAST) software; version 3.13 and Excel 2010.

\section{Results and Discussion}

The seasonal results of concentrations of $\mathrm{Pb}, \mathrm{Cd}, \mathrm{Cr}, \mathrm{Ni}$, $\mathrm{Co}, \mathrm{Cu}, \mathrm{Zn}, \mathrm{Mn}, \mathrm{Mg}$ and $\mathrm{Fe}$ in mangrove sediments collected from the study area have been represented in Figure 2.

\section{Lead (Pb)}

Lead rarely exist in nature and could be found in different forms such as organic and inorganic compounds [21]. The presence of $\mathrm{Pb}$ may also affect the gastrointestinal tract, kidneys and the central nervous system [22]. Exposure to lead could lead to loss of memory, nausea, insomnia, anorexia, and weakness of the joints, failures of reproduction, inhibition of haem synthesis, irritation and producing tumour [23]. Lead is non essential element as it is toxic even in trace amount [24]. Its uses include storage batteries, solders, bearings, cable covers, ammunition, plumbing, pigments, caulking, sound and vibration absorbers [25].

The concentrations of $\mathrm{pb}$ in mangrove sediments ranged between $6.6 \mu \mathrm{g} / \mathrm{g}$ at Yakhtol in January and $16.6 \mu \mathrm{g} / \mathrm{g}$ at Al-Hodeidah, in August. A baseline $\mathrm{Pb}$ value for surface soil on the global scale has been estimated to be $10 \mu \mathrm{g} / \mathrm{g}$ levels above this suggest an anthropogenic influence [26]. Al-Hodeidah only showed a slightly rise above this level $(10 \mu \mathrm{g} / \mathrm{g})$, compared to other areas of the present study. This may be due to increased human activities in the city. In addition to this, their site is located close to the sewage treatment plant, as well as AlHodeidah harbor.

The background value of $\mathrm{Pb}$ in the stream sediments and floodplain sediments is $14 \mu \mathrm{g} / \mathrm{g}$ and $16 \mu \mathrm{g} / \mathrm{g}$, respectively, and in the earth's upper continental crust, it is $17 \mu \mathrm{g} / \mathrm{g}[26,27]$. In marine sediments, it ranges from (7$13 \mu \mathrm{g} / \mathrm{g}$ ) [28]. The present results of $\mathrm{Pb}$ are within the range of the background level of marine sediments. The values of $\mathrm{Pb}$ in mangrove sediment were found to be lower than the concentrations recommended by USEPA and CCME for the protection of aquatic life. Based on background values of $\mathrm{Pb}$, mangrove sediments of the study area could be classified as uncontaminated except Al-Hodeidah station which exhibited a beginning of pollution in mangrove sediments $[29,30]$.

Sources of $\mathrm{Pb}$ in mangrove ecosystems include wastes and from water pipes [31]. Other sources of $\mathrm{Pb}$ are lead acid batteries, solder, alloys, cable sheathing, pigments, rust inhibitors, ammunition, glazes and plastic stabilizers [32].

\section{Cadmium (Cd)}

Cadmium is an element found naturally in the environment. It is a toxic metal even at low levels [33]. Small quantities of $\mathrm{Cd}$ cause adverse changes in the arteries of human kidney and replaces zinc biochemically and causes high blood pressures and kidney damage [34]. It interferes with enzymes and causes a painful disease called Itai-itai [1].

Mangrove sediments showed a narrow range of $\mathrm{Cd}$ levels. It ranged from undetectable levels at Al-Salif in January and Yaktol in January and October to $0.57 \mu \mathrm{g} / \mathrm{g}$ at Al-Hodeidah in April. Cd is a relatively rare in the Earth's upper continental crust with an average value of $0.098 \mu \mathrm{g} / \mathrm{g}$ [27]. The main sources of cadmium in the 


\section{Journal of Ecology \& Natural Resources}

marine environment are anthropogenic activities [35] High levels of $\mathrm{Cd}$ in mangrove sediments at $\mathrm{Al}$-Hodeidah and Ghorairah may be due to anthropogenic activities. At Al-Hodeidah may be attributed to the discharge of untreated, sewage, domestic garbage dumps, boating activities, metal plating and coating operations. Whereas at Ghorairah it could be attributed to the potential contaminants that carried by water currents coming from the Gulf of Aden as it is located the area near to Bab-elMandeb Strait.

The background value of $\mathrm{Cd}$ in marine sediments is ranged from 0.1 to $0.3 \mu \mathrm{g} / \mathrm{g}$, whereas in the stream sediments and floodplain sediments it found to be $0,28 \mu \mathrm{g} / \mathrm{g}$ and $0.30 \mu \mathrm{g} / \mathrm{g}$, respectively $[26,28]$. This study found levels of $\mathrm{Cd}$ in mangrove sediments at Al-Hodeidah, Ghorairah and Al-Urj slightly higher than expected natural background levels. This might be classified as low contaminated. Al-Salif and Yakhtol may be classified as unpolluted. As general, the levels of $\mathrm{Cd}$ in the studied sediment were found to be lower than the concentration recommended by USEPA and CCME for the protection of aquatic life $[29,30]$.

Cadmium in mangrove ecosystems of the study area could be derived from both natural and anthropogenic sources. Natural sources include underlying bedrock or transported parent material such as alluvium. Anthropogenic sources include industrial effluents, wastes, urban runoff, burning of fossil fuels, sewage treatment plants, boating activities, aerial deposition, sewage, domestic garbage dumps, manure, phosphate and fertilizers application $[35,36]$.

\section{Chromium (Cr)}

Chromium does not occur naturally in elemental form but only in compounds [35]. It is an essential nutrient, which is essential for carbohydrate metabolism in animals [25]. Cr and its compounds are known to cause cancer of the lung, nasal cavity and suspected to cause cancer of the stomach and larynx [37]. Exposure to $\mathrm{Cr}$ could lead to allergic dermatitis in humans, bleeding of the gastrointestinal tract, cancer of the respiratory tract and ulcers of the skin, then also damage to the mucus membrane, liver and kidney damage [38]. Most elevated levels of $\mathrm{Cr}$ in aquatic ecosystems are a consequence of industrial activity [39]. $\mathrm{Cr}$ is found at contaminated sites and toxic levels are common in soils applied with sewage sludge [40].

The present value of $\mathrm{Cr}$ in mangrove sediments ranged from $15.3 \mu \mathrm{g} / \mathrm{g}$ at Yakhtol in August to $35.6 \mu \mathrm{g} / \mathrm{g}$ at Al-
Hodeidah in April. Sources of $\mathrm{Cr}$ in mangrove ecosystems could be attributed to the industrial and sewage wastes [31]. Therefore, the high levels of $\mathrm{Cr}$ at $\mathrm{Al}$-Hodeidah may be due to partially treated sewage outflow from the city sewage plant, as well as Al-Hodeidah harbor. At Ghorairah, it could be attributed to the potential contaminants coming from the Gulf of Aden through Babel-Mandeb Strait. Slightly high concentrations were at AlUrj, this may be due to that the habitat is located near a recreation area where it is visited by local tourists, as well as the steam power plant.

The background value of $\mathrm{Cr}$ in the stream sediments and floodplain sediments is $21 \mu \mathrm{g} / \mathrm{g}$ and $23 \mu \mathrm{g} / \mathrm{g}$, respectively, whereas in the earth's upper continental crust, it is $92 \mu \mathrm{g} / \mathrm{g}[26,27]$. A baseline $\mathrm{Cr}$ value for surface soil on the global scale has been estimated to be $24 \mu \mathrm{g} / \mathrm{g}$ [26]. The background value of $\mathrm{Cr}$ in marine sediments is ranged from $4 \mu \mathrm{g} / \mathrm{g}$ to $17 \mu \mathrm{g} / \mathrm{g}$, with $<19 \mu \mathrm{g} / \mathrm{g}$ in unpolluted sediments, with $<25 \mu \mathrm{g} / \mathrm{g}$ in unpolluted sediments $[28,29,41]$. According to Sediment Quality Guidelines and background levels of $\mathrm{Cr}$, mangrove sediments at Al-Hodeidah exhibited low to moderately polluted sediments, whereas at Ghorairah and Al-Urj reported low polluted sediments. Al-Salif and Yakhtol showed unpolluted sediments. Generally, the level of $\mathrm{Cr}$ in mangrove sediments does not exceed threshold effect level $(52.3 \mu \mathrm{g} / \mathrm{g})$ or probable effect levels $(160 \mu \mathrm{g} / \mathrm{g})$ as proposed by CCME [30].

Natural source of $\mathrm{Cr}$ in the environment could be derived from the weathering of rocks and soil, whereas major anthropogenic sources includes metal alloy production, metal plating for prevention of corrosion, tannery wastes, cement manufacturing, leather manufacturing wastes, paint pigments, incineration of municipal refuse and sewage sludge [40].

\section{Nickel (Ni)}

Nickel is an element that occurs in the environment only at very low levels and is essential in small doses. It could be dangerous when the maximum tolerable amounts are exceeded [35]. Ni could result in lung, liver and kidney damage. In high quantities Ni could also cause cancer, respiratory failure, birth defects, allergies, dermatitis, eczema, nervous system and heart failure [23].

The values of $\mathrm{Ni}$ in mangrove sediments ranged from $15.5 \mu \mathrm{g} / \mathrm{g}$ at Yakhtol in January to $34.7 \mu \mathrm{g} / \mathrm{g}$ at AlHodeidah in August. A baseline Ni value for surface soil on the global scale has been estimated to be $26 \mu \mathrm{g} / \mathrm{g}$, above this suggest an anthropogenic influence [26]. Al- 


\section{Journal of Ecology \& Natural Resources}

Hodeidah, only showed a rise above this level $(26 \mu \mathrm{g} / \mathrm{g})$, compared to other areas. This may be due to increased anthropogenic activities in the city. In addition to this, the site is located close to the sewage treatment plant, as well as Al-Hodeidah harbor which in the main Yemeni on the Red Sea.

The average value of $\mathrm{Ni}$ in the stream sediments and floodplain sediments is $16 \mu \mathrm{g} / \mathrm{g}$ and $18 \mu \mathrm{g} / \mathrm{g}$, respectively [26]. In the earth's upper continental crust, it is of $47 \mu \mathrm{g} / \mathrm{g}$ [27]. The background value of $\mathrm{Ni}$ in marine sediments is ranged from $10 \mu \mathrm{g} / \mathrm{g}$ to $25 \mu \mathrm{g} / \mathrm{g}$, with $<33 \mu \mathrm{g} / \mathrm{g}$ in unpolluted sediments, with $<20 \mu \mathrm{g} / \mathrm{g}$ in unpolluted sediments $[28,29,41]$. Ni in mangrove sediments was within the range of the background level of marine sediments at all sites excepted at Al-Hodeidah. Mangrove sediments at Al-Hodeidah could be classified as moderately contaminated as recommended by USEPA and CCME for the protection of aquatic life. Ghorairah, Al-Urj and Al-Salif showed a slight pollution in mangrove sediments $[29,30]$. The level of $\mathrm{Ni}$ in all studied sediments exceeds threshold effect level $(15.9 \mu \mathrm{g} / \mathrm{g})$, whereas it does not exceed probable effect levels $(42.8 \mu \mathrm{g} / \mathrm{g})$ as proposed by CCME [30].

Ni contaminations in mangrove ecosystems are metal plating industries, combustion of fossil fuels and electroplating. Other sources of $\mathrm{Ni}$ include weathering process of exposed soil, decaying vegetation and the $\mathrm{Ni} / \mathrm{Cd}$ batteries dumped in these sites $[25,38]$.

\section{Cobalt (Co)}

Cobalt naturally occurs in the earth's crust, and considered to be an essential mineral to living organisms [42]. It is a part of vitamin B12, which is essential component for human health [38]. Co is also used to treat anemia with pregnant women because it stimulates the production of red blood cells [43]. On the other hand, Co could cause bronchial asthma, interstitial lung disease, lung cancer, pneumonia, heart problems, thyroid damage, nausea, vomiting and diarrhoea [44]. Cobalt could be used in electroplating, as a ground coats for porcelain enamels, magnetic steels, some types of stainless steels and alloys for jet engines and gas turbines [45].

During the present research work, it is found that concentration of Coin mangrove sediments ranged between $6.2 \mu \mathrm{g} / \mathrm{g}$ in January at Al-Urj and $15.8 \mu \mathrm{g} / \mathrm{g}$ in at Al-Hodeidah. The background values of Co in marine sediments is $10 \mu \mathrm{g} / \mathrm{g}$, and in the stream sediments and floodplain sediments it is found to be $8.0 \mu \mathrm{g} / \mathrm{g}$ and $7.0 \mu \mathrm{g} / \mathrm{g}$, respectively [26,28]. In the earth's upper continental crust, it is $17.3 \mu \mathrm{g} / \mathrm{g}$ [27]. The present results of Co are considerably higher than background level at AlHodeidah and Ghorairah. Based on background level of Co, mangrove sediments at Ghorairah could be classified low contaminated, whereas at $\mathrm{Al}$-Hodeidah it may be classified low to moderate contaminated. Al-Salif, Al-Urj and Yakhtol exhibited beginning of contamination of mangrove sediments.

The sediments collected from mangrove environment at Al-Hodeidah showed slightly higher level of Co than other sites. It could be attributed to burning of fossil fuels, sewage sludge and phosphate fertilizers. In addition, it could be due to the discharge of agricultural and industrial wastes from the surrounding area.

Naturally, Co could be discharged into the environment from wind-blown dust, seawater spray, volcanoes and continental and marine biogenic emissions [46]. Anthropogenic sources of Cobalt could be from burning of fossil fuels, sewage sludge, phosphate fertilizers, processing of cobalt alloys and industries that use or process cobalt compounds [44].

\section{Copper (Cu)}

Copper is one of the world's most widely used metals and is regarded as a potential hazard [47]. High doses of $\mathrm{Cu}$ cause anaemia, stomach and intestinal irritation, neurological complications, liver and kidney damage [38]. It could also be described as a toxic waste and therefore unpalatable for consumption [23]. There are many industrial uses of $\mathrm{Cu}$, due to its high ductility, malleability, thermal conductivity and resistance to corrosion [48]. It is used as a component in metal alloys, electrical wiring, preservatives for wood, leather and fabrics [25].

The values of $\mathrm{Cu}$ in mangrove sediments in the present investigation ranged from $12.3 \mu \mathrm{g} / \mathrm{g}$ in October at Yakhtol to $40.7 \mu \mathrm{g} / \mathrm{g}$ in August at Al-Hodeidah. High levels of $\mathrm{Cu}$ in mangrove sediments at $\mathrm{Al}$-Hodeidah may be attributed to human activities such as; discharge of untreated, sewage, domestic garbage dumps, boating activities, coating operations, and metal plating.

The background value of $\mathrm{Cu}$ level in marine sediments is $9.9 \mu \mathrm{g} / \mathrm{g}$ [28]. It is a moderately abundant heavy metal with an average concentration of $\mathrm{Cu}$ in the stream sediments and floodplain sediments is $14 \mu \mathrm{g} / \mathrm{g}$ and $19 \mu \mathrm{g} / \mathrm{g}$, respectively [26]. Whereas in the earth's upper continental crust, it is $28 \mu \mathrm{g} / \mathrm{g}$ [27], with $<25 \mu \mathrm{g} / \mathrm{g}$ in unpolluted sediments [29]. A baseline $\mathrm{Cu}$ value for surface soil on the global scale has been estimated to be $14 \mu \mathrm{g} / \mathrm{g}$, 


\section{Journal of Ecology \& Natural Resources}

whereas the average of $\mathrm{Cu}$ levels in soil vary from 13 to $24 \mu \mathrm{g} / \mathrm{g}[26,42]$. Therefore, according to background levels of $\mathrm{Cu}$, mangrove sediments at Ghorairah, Al-Salif and Yakhtol showed low polluted sediments, whereas at Al-Hodeidah it exhibited moderately polluted sediments as recommended by USEPA and CCME for the protection of aquatic life $[29,30]$. The level of $\mathrm{Cu}$ at $\mathrm{Al}$-Hodeidah also exceed effects range low $(34 \mu \mathrm{g} / \mathrm{g})$. Generally, the level of $\mathrm{Cu}$ in all analyzed sediments exceed threshold effect level $(18.7 \mu \mathrm{g} / \mathrm{g})$, whereas it does not exceed probable effect levels $(108 \mu \mathrm{g} / \mathrm{g})$ as proposed by CCME [30].

Naturally, copper could be discharged into the environment from forest fires, weathering process of exposed soil and decaying vegetation. Anthropogenic source of copper may originate from domestic use of copper-based chemicals, municipal untreated sewage sludge and corrosion of copper materials [49]. In addition to domestic and industrial wastewaters, steam electrical production, incinerator emissions and the dumping of sewage sludge [50].

\section{Zinc (Zn)}

Zinc is widely distributed in nature. It is a very common environmental contaminant [51]. $\mathrm{Zn}$ is an essential nutrient for the human body and has an importance for health [52]. High levels of Zn could cause health problems such as stomach cramps, skin irritations, vomiting, nausea, anaemia, headaches, loss of appetite and some respiratory disorders [53]. $\mathrm{Zn}$ is widely used in modern society, most commonly to coat or galvanise iron to prevent corrosion [54]. It is also mixed with other metals to form alloys such as brass or bronze, particles released from vehicle tyres and brake linings are a major source of zinc in the environment, and it is used in manufacture of dry cell batteries, paints, rubber, plastics and cosmetics $[55,56]$.

The concentrations of $\mathrm{Zn}$ in mangrove sediments ranged from $27.5 \mu \mathrm{g} / \mathrm{g}$ at Yakhtol in April to $57.2 \mu \mathrm{g} / \mathrm{g}$ at Al-Hodeidah in April. Relatively high concentrations of $\mathrm{Zn}$ at Al-Hodeidah could be due to increasing anthropogenic activities in the vicinity of these sites. At Ghorairah may be attributed to the potential pollutions that carried by water currents coming from the Gulf of Aden. In addition, the located these sites close to Bab-el-Mandeb Strait. Sediments from uncontaminated waters typically contain $\mathrm{Zn}$ concentration in the order of $5-50 \mu \mathrm{g} / \mathrm{g}$ [47]. The average value of $\mathrm{Zn}$ in the stream sediments and floodplain sediments is $60 \mu \mathrm{g} / \mathrm{g}$ and $56 \mu \mathrm{g} / \mathrm{g}$, respectively [26]. In the earth's upper continental crust, it is $47 \mu \mathrm{g} / \mathrm{g}$ [27]. The background value of $\mathrm{Zn}$ in marine sediments is ranged from $7 \mu \mathrm{g} / \mathrm{g}$ and $38 \mu \mathrm{g} / \mathrm{g}$, with $<95 \mu \mathrm{g} / \mathrm{g}$ in unpolluted sediments, with $<90$ in unpolluted sediments $[28,29,41]$. A baseline $\mathrm{Zn}$ value for surface soil on the global scale has been estimated to be $44 \mu \mathrm{g} / \mathrm{g}$ [26].

The level of $\mathrm{Zn}$ in the analyzed sediments does not exceed threshold effect level $(124 \mu \mathrm{g} / \mathrm{g})$ or probable effect levels $(270 \mu \mathrm{g} / \mathrm{g})$ as proposed by CCME [30]. Therefore, based on background value of $\mathrm{Zn}$, mangrove sediments at all sites showed unpolluted.

Main sources of $\mathrm{Zn}$ discharge into mangrove ecosystems include automobiles, petroleum refining, pulp and paper industry, steel industry, organic chemicals, inorganic chemicals, fertilizers and metal plating $[57,58]$. The other possible sources of $\mathrm{Zn}$ are from motor oil, grease, phosphate fertilizers, sewage sludge, transmission fluid, and concrete [59].

\section{Manganese (Mn)}

Manganese is found in many, widely scattered minerals [42]. $\mathrm{Mn}$ is an essential plant mineral nutrient, playing a key role in several physiological processes, particularly photosynthesis [60]. Mn toxicity in humans mainly affects the respiratory tract and the brain; symptoms include hallucinations, forgetfulness and nerve damage [43]. It could also cause lung embolism, Parkinson's disease and bronchitis, It is more common than toxicity, and causes impaired reproduction and growth [61]. It used for production of ferromanganese steels, glass, electrolytic manganese dioxide for use in batteries, alloys, catalysts, antiknock agents, pigments, dryers, wood preservatives and coating welding rods [58].

The values of $\mathrm{Mn}$ in mangrove sediments ranged from $195.8 \mu \mathrm{g} / \mathrm{g}$ in January at Yakhtol to $528.0 \mu \mathrm{g} / \mathrm{g}$ in August at Al-Hodeidah. A baseline Mn value for surface soil on the global scale has been estimated to be $382 \mu \mathrm{g} / \mathrm{g}$ [26]. The average concentration of $\mathrm{Mn}$ in the stream sediments and floodplain sediments is $452 \mu \mathrm{g} / \mathrm{g}$ and $446 \mu \mathrm{g} / \mathrm{g}$, respectively, whereas in the earth's upper continental crust, it is of $1000 \mu \mathrm{g} / \mathrm{g}[26,27]$. The global average for Mn in soil has been estimated as $437 \mu \mathrm{g} / \mathrm{kg}$ [42]. The background value of $\mathrm{Mn}$ in marine sediments is $400 \mu \mathrm{g} / \mathrm{g}$, with $<770 \mu \mathrm{g} / \mathrm{g}$ in unpolluted sediments $[28,41]$. Mn value in mangrove sediments are within the range of background level of marine sediments at all sites.

Mangrove sediments at Al-Hodeidah exposed high value of $\mathrm{Mn}$, indicating that these sediments might be affected by increased human activities in the city. In addition to this, their site is located close to the sewage 


\section{Journal of Ecology \& Natural Resources}

treatment plant, as well as Al-Hodeidah harbor. Based on background level of $\mathrm{Mg}$, Mangrove sediments at $\mathrm{Al}$ Hodeidah showed low pollution; At Ghorairah it exhibited a beginning of pollution in mangrove sediments. At AlSalif, Al-Urj and Yakhtol it may be classified as unpolluted. Natural sources of $\mathrm{Mn}$ in mangrove ecosystems are weathering of rocks and soils, decaying vegetation [62]. Anthropogenic source municipal wastewater discharges, sewage, sludge, emissions from ferroalloy and $\mathrm{Fe}$ production, as well as combustion of fossil fuels [63].

\section{Magnesium (Mg)}

Magnesium occurs naturally only in combination with other elements, in humans; $\mathrm{Mg}$ is found in large deposits in minerals [26]. It is essential to the working of hundreds of enzymes [64]. Mg prevents and manages hypertension, cardiovascular disease, most importantly diabetes and joint pains [65]. The main applications of $\mathrm{Mg}$ are aluminium alloys; it is used in products that benefit from being lightweight, such as car seats, luggage, laptops, cameras and power tools [66].

The level of $\mathrm{Mg}$ in mangrove sediments ranged from $915.2 \mu \mathrm{g} / \mathrm{g}$ in January at Yakhtol to 2,066.0 $\mu \mathrm{g} / \mathrm{g}$ in August at Al-Hodeidah. High levels of $\mathrm{Mg}$ in mangrove ecosystem at Al-Hodeidah might be attributed to the discharges, spills from industrial and municipal waste treatment plants, and fertilizers, as well as decaying vegetation, organic and mineral fertilization practice. The average value of $\mathrm{Mg}$ in the stream sediments and floodplain sediments is $1,200 \mu \mathrm{g} / \mathrm{g}$, whereas in the earth's upper continental crust, it is 2,480 $\mathrm{gg} / \mathrm{g}$ [26,27]. A baseline $\mathrm{Mg}$ value for surface soil on the global scale has been estimated to be770 $\mu \mathrm{g} / \mathrm{g}$, with an average value it is $1,500 \mu \mathrm{g} / \mathrm{g}$ in shale sediments [26,67]. According to background levels of $\mathrm{Mg}$, mangrove sediments at $\mathrm{Al}$ Hodeidah exhibited low to moderate contaminated, at Ghorairah and Al-Urj it showed low contaminated.

Naturally, Mg may be discharged into mangrove ecosystem from weathering process of exposed soil, and decaying vegetation, while anthropogenic sources include discharges, fertilizers, spills from industrial and municipal waste treatment plants [68].

\section{Iron (Fe)}

Iron, one of the most abundant metals on Earth [26]. It is essential to most life forms and to normal human physiology; it is an integral part of many proteins and enzymes that maintain good health [69]. In humans, Fe is an essential component of proteins involved in oxygen transport, it is also essential for the regulation of cell growth and differentiation [70]. Its main role in humans is in the production of haemoglobin in red blood cells [71]. A deficiency of Fe limits oxygen delivery to cells, resulting in fatigue, poor work performance and decreased immunity [72]. On the other hand, excess amounts of iron in man could result in toxicity and even death [73].

The levels of $\mathrm{Fe}$ in mangrove sediments ranged from $8,432.4 \mu \mathrm{g} / \mathrm{g}$ at Yakhtol in October to $15,255.2 \mu \mathrm{g} / \mathrm{g}$ at $\mathrm{Al}-$ Hodeidah in April. Mangrove sediments collected from AlHodeidah and Ghorairah showed slightly higher levels of Fe than other sites. However, the high levels of Fe in AlHodeidah, may be due to partially treated sewage outflow from the city sewage plant, as well as Al-Hodeidah harbor. At Ghorairah might be attributed to the potential contaminants which loaded by water currents coming from the Gulf of Aden through Bab-el-Mandeb Strait.

The background level of $\mathrm{Fe}$ in marine sediments is ranged from 9,900 to $18,000 \mu \mathrm{g} / \mathrm{g}$, with $<41,000 \mu \mathrm{g} / \mathrm{g}$ in unpolluted sediments [28,41]. A baseline Fe value for surface soil on the global scale has been estimated to be $19,600 \mu \mathrm{g} / \mathrm{g}$ [26]. The average concentration of Fe in the stream sediments and floodplain sediments is $19,700 \mu \mathrm{g} / \mathrm{g}$ and $19,500 \mu \mathrm{g} / \mathrm{g}$, respectively [26]. In the earth's upper continental crust, it is $50,400 \mu \mathrm{g} / \mathrm{g}$ [27]. The present results of $\mathrm{Fe}$ are considerably lower than background level. According to background level of $\mathrm{Fe}$, mangrove sediments could be classified as unpolluted.

Fe is released into mangrove environments by natural process, such as weathering of sulphide ores and rocks [27]. Anthropogenic sources of iron include the iron and steel industry, burning of coke and coal, sewage, landfill leachates and the corrosion of iron and steel [42].

Comparing the concentrations of studied heavy metals in mangrove sediments of the study area with those from other studies conducted within the same geographical region and other countries shown in Table 2.

\section{Correlation Coefficient Analysis of Heavy Metals in Mangrove Sediments}

Significant positive correlations between heavy metals in sediments may suggest that these heavy metals had common sources [74]. The present study found a positive correlation between $\mathrm{Cd}$ and $\mathrm{Mg}$ (0.592) in sediments, which indicate that $\mathrm{Cd}$ and $\mathrm{Mg}$ have a similar contamination sources and/or natural origin. The positive correlations of $\mathrm{Zn}$ with $\mathrm{Fe} / \mathrm{Mn}$ indicate the significance of inorganic transfer mechanisms in aquatic systems, as 
reported by Fang and Hong [75]. According to Horowitz and Elrick, iron oxides also play an important role in trapping metals in aquatic sediments [76]. Ray, et al. and Sarkar, et al. showed that $\mathrm{Zn}$ has positive correlations with $\mathrm{Fe}$ and $\mathrm{Mn}$, also the present investigation confirmed that $\mathrm{Zn}$ has a high positive correlation between with $\mathrm{Fe}$ (0.702) and $\mathrm{Mn}$ (0.802) [32,77]. The present study assumes that the distribution pattern of $\mathrm{Zn}$ is closely related to the iron-rich deposits due to high adsorption between these metals. Fe exhibited positive correlations with Mn (0.855). Fe and Mn occur naturally at abundant levels and are thus barely affected by anthropogenic activities, which explain their apparent correlation in the sediments [77]. This study revealed that Fe showed a positive correlation with $\mathrm{Mn}$ (0.855), Zn (0.702) and Co (0.725). This is indicating that these metals may originate from similar pollution sources. The correlations with $\mathrm{Fe}$ and heavy metals have also been used to distinguish between the natural levels of heavy metals and anthropogenically enriched ones [78]. Good correlations between $\mathrm{Fe}$ and trace metal concentrations are expected for unpolluted sediments [79]. According to Fergusson, Barreiro, et al.and Sharma, et al. $\mathrm{Pb}$ is strongly sorbed to $\mathrm{Fe} / \mathrm{Mn}$ oxides, which are reported to be more important than association with clays and organic materials [80-82].

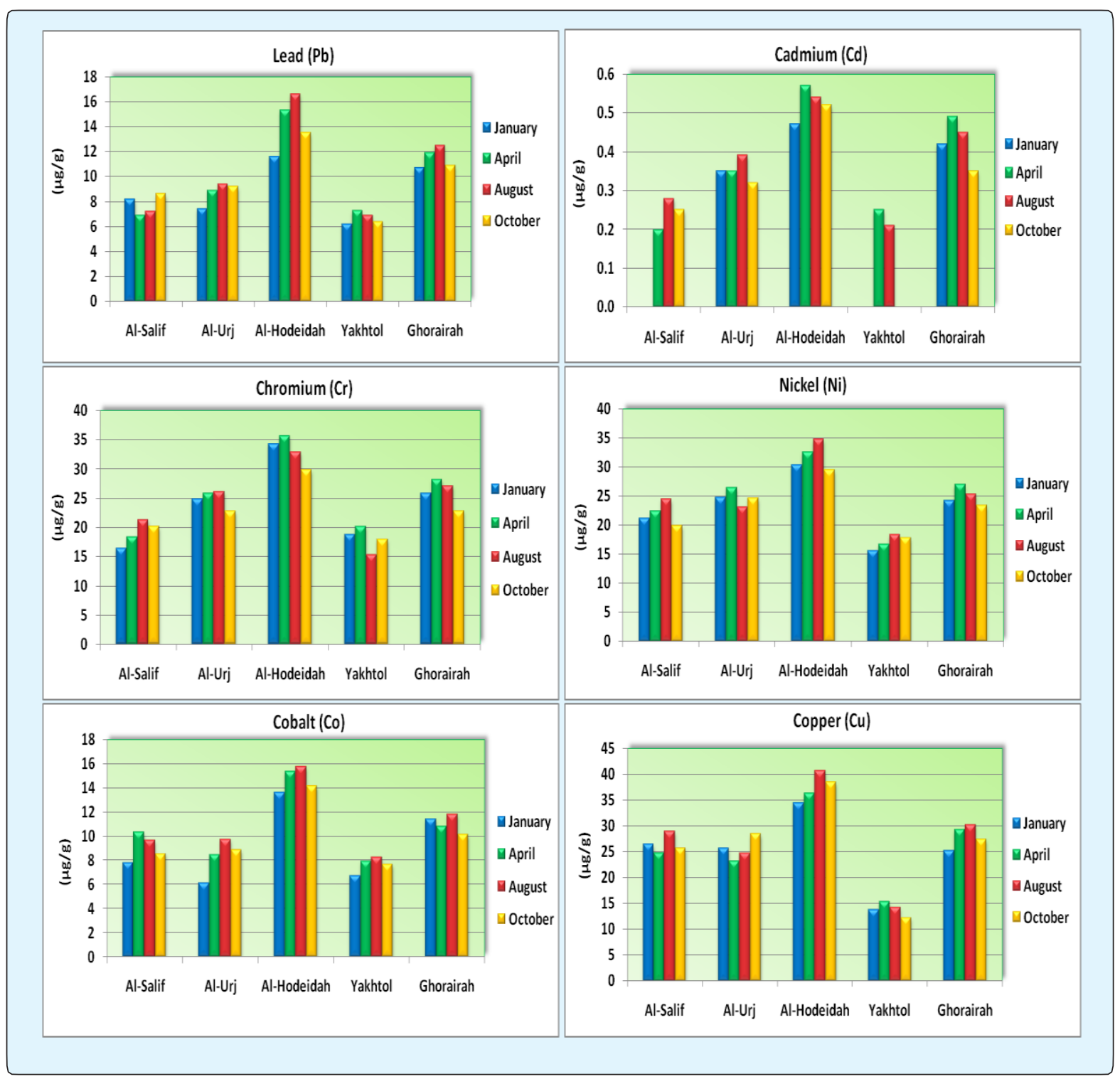

Al Hagibi HA, et al. Study of Heavy Metals contamination in Mangrove Sediments of the Red Sea Coast of Yemen from Al-Salif to Bab-el-Mandeb Strait. J Ecol \& Nat Resour 2018, 2(1): 


\section{Journal of Ecology \& Natural Resources}
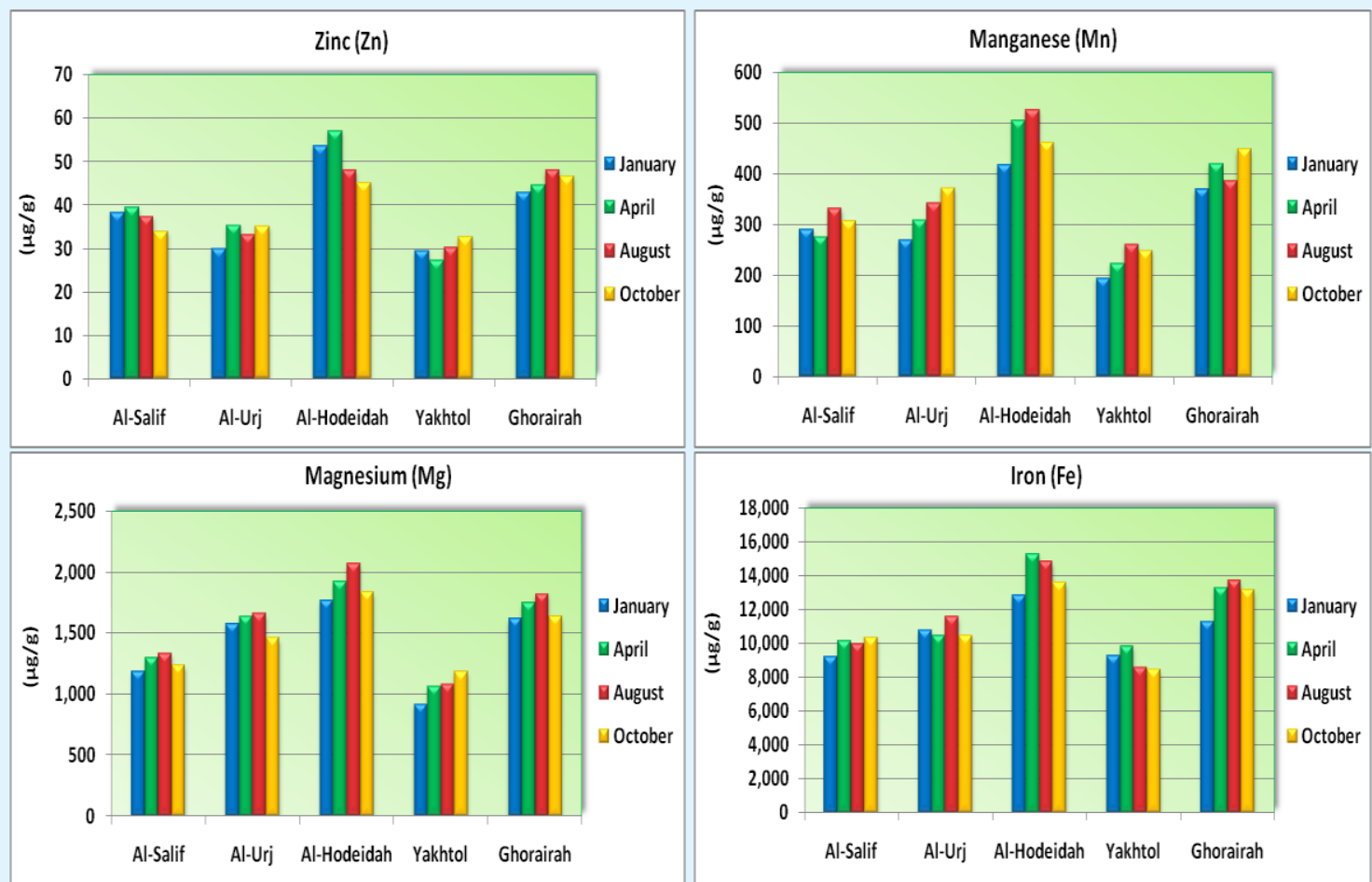

Figure 2: Seasonal variations of heavy metals concentrations $(\mu \mathrm{g} / \mathrm{g})$ in mangroves sediments.

\begin{tabular}{|c|c|c|c|c|c|c|c|c|c|c|c|c|}
\hline \multicolumn{2}{|c|}{ Location } & $\mathbf{P b}$ & Cd & $\mathrm{Cr}$ & $\mathbf{N i}$ & Co & $\mathrm{Cu}$ & $\mathbf{Z n}$ & Mn & Mg & $\mathbf{F e}$ & Reference \\
\hline \multirow{5}{*}{$\begin{array}{l}\text { Red Sea } \\
\text { coast of } \\
\text { Yemen }\end{array}$} & Al-Salif & 7.73 & 0.18 & 19.05 & 21.93 & 9.14 & 26.43 & 37.43 & 302.14 & 1262.04 & 9920.59 & \multirow{5}{*}{ Present study } \\
\hline & Al-Urj & 8.73 & 0.35 & 24.85 & 24.70 & 8.35 & 25.48 & 33.50 & 324.53 & 1579.46 & 10812.46 & \\
\hline & Al-Hodeidah & 14.25 & 0.53 & 33.10 & 31.73 & 14.78 & 37.43 & 51.05 & 478.83 & 1895.54 & 14113.94 & \\
\hline & \begin{tabular}{|l} 
Yakhtol \\
\end{tabular} & 6.70 & 0.12 & 18.05 & 17.08 & 7.69 & 13.93 & 30.03 & 233.39 & 1058.18 & 9019.30 & \\
\hline & Ghorairah & 11.50 & 0.43 & 24.93 & 24.93 & 11.09 & 28.00 & 45.63 & 407.39 & 1703.44 & 12835.33 & \\
\hline \multirow{3}{*}{$\begin{array}{l}\text { Saudi } \\
\text { Arabia }\end{array}$} & Shuaiba & 0.53 & 0.02 & 8.74 & 27.42 & - & 4.16 & 2.80 & 61.28 & - & 1810.0 & \multirow{2}{*}{$\begin{array}{l}\text { Abohassan, } \\
\text { (2013) [83] }\end{array}$} \\
\hline & Yanbu & 3.84 & 0.20 & 11.51 & 24.80 & - & 13.97 & 13.52 & 150.14 & - & 8825.9 & \\
\hline & $\begin{array}{c}\text { Farasan } \\
\text { Island }\end{array}$ & ND & ND-1.04 & 4.1-14.9 & $.37-4.0$ & - & $256-356.6$ & $29.5-36.8$ & - & - & - & $\begin{array}{l}\text { Usman, et al. } \\
\text { (2013) [84] }\end{array}$ \\
\hline \multirow{2}{*}{ Egypt } & $\begin{array}{l}\text { Abu-Minqar } \\
\text { Island }\end{array}$ & 12.80 & 0.40 & - & - & - & 18.30 & 37.60 & 479.60 & - & 3009.7 & \multirow{2}{*}{$\begin{array}{l}\text { Dar and El- } \\
\text { Saharty, } \\
(2006) \text { [85] }\end{array}$} \\
\hline & $\begin{array}{l}\text { Safaga } \\
\text { Island } \\
\end{array}$ & 28.40 & 0.40 & - & - & - & 67.50 & 49.50 & 322.20 & - & 2486.0 & \\
\hline United $A$ & Irab Emirates & $20.4-37.3$ & 3 | $4.5-5.1$ & $10.2-14.1$ & $8.0-76$. & $1-11$ & $6.3-9.1$ & $9.0-13.2$ & 9.9-111. & - & - & $\begin{array}{c}\text { Shriadah, } \\
\text { (1999) [86] }\end{array}$ \\
\hline \multirow{4}{*}{ Iran } & Qeshm Island & 43.61 & - & - & 54.12 & - & 42.13 & 47.90 & - & - & - & $\begin{array}{l}\text { Einollahipeer, } \\
\text { t al. (2013) [87 }\end{array}$ \\
\hline & $\begin{array}{l}\text { Sirik Azini } \\
\text { creek }\end{array}$ & 32.31 & 18.93 & - & 99.41 & - & 26.48 & 151.75 & - & - & - & $\begin{array}{c}\text { Parvaresh, et al. } \\
\text { (2011) [88] }\end{array}$ \\
\hline & Booshehr & 94.80 & - & - & 64.14 & - & 46.04 & 181.46 & - & - & - & $\begin{array}{l}\text { Davari, et al. } \\
\text { (2012) [89] }\end{array}$ \\
\hline & Kannur & 28.00 & 2.00 & - & - & 52.00 & 47.00 & 66.00 & 395.00 & - & 37100.0 & Badarudeen, et \\
\hline
\end{tabular}




\section{Journal of Ecology \& Natural Resources}

\begin{tabular}{|c|c|c|c|c|c|c|c|c|c|c|c|c|}
\hline \multirow{4}{*}{ India } & & & & & & & & & & & & al. (2014) [90] \\
\hline & $\begin{array}{c}\text { Gulf of } \\
\text { Mannar }\end{array}$ & 16.00 & 0.16 & 177.00 & 24.00 & 15.00 & 57.00 & 73.00 & 305.00 & - & 12600.0 & $\begin{array}{c}\text { Jonathan, et al. } \\
\text { (2009) [56] }\end{array}$ \\
\hline & Cuddalore & 8.00 & 0.10 & 22.00 & 5.00 & 1.80 & 196.00 & 65.00 & 41.00 & 1752.0 & 3887.0 & $\begin{array}{c}\text { Kathiresan, } \\
\text { et al. } \\
\text { (2014) [91] }\end{array}$ \\
\hline & Godavari & 55.80 & 10.90 & 2.20 & 25.70 & 28.80 & 47.80 & - & 1059.00 & - & 4575.0 & $\begin{array}{l}\text { Ray, et al. } \\
\text { (2006) [77] }\end{array}$ \\
\hline Thailand & Pattani Bay & 47.30 & 0.20 & 58.30 & 16.90 & - & 22.10 & 26.60 & 101.40 & - & - & $\begin{array}{c}\text { Kaewtubtim } \\
\text { et al. (2016) }\end{array}$ \\
\hline Singapore & $\begin{array}{c}\text { Khatib } \\
\text { Bongsu }\end{array}$ & 30.98 & 0.26 & 32.07 & 11.65 & - & 32.00 & 120.23 & - & - & - & $\begin{array}{l}\text { Cuong, et al. } \\
\text { (2005) [92] }\end{array}$ \\
\hline \multirow{2}{*}{ anglades } & Sundarbans & 25.61 & 0.09 & 52.87 & 207.31 & - & 44.69 & 74.09 & 740.95 & - & 42172.0 & $\begin{array}{l}\text { Kumar et al. } \\
\text { (2016) [93] }\end{array}$ \\
\hline & Sundarbans & 19.30 & 0.55 & 15.70 & 76.10 & - & 10.50 & 73.60 & 436.80 & - & 17389.0 & $\begin{array}{l}\text { Awal, et al. } \\
\text { (2009) [94] }\end{array}$ \\
\hline \multirow{3}{*}{ China } & Futian & 133.30 & 0.98 & 30.28 & - & - & 69.80 & 193.72 & - & - & - & $\begin{array}{c}\text { Li, et al. (2008) } \\
{[95]}\end{array}$ \\
\hline & Maowei Gulf & 18.31 & 0.34 & 30.02 & 9.24 & - & 24.81 & 59.85 & - & - & - & $\begin{array}{c}\text { Wu, et al. } \\
(2015)[96]\end{array}$ \\
\hline & Quanzhou Bay & 61.60 & - & 21.90 & 8.19 & 4.49 & 49.00 & 62.00 & 943.00 & - & 7596.0 & $\begin{array}{c}\text { Yu, et al. } \\
\text { (2015) [97] }\end{array}$ \\
\hline Panama & $\begin{array}{c}\text { Punta Mala } \\
\text { Bay }\end{array}$ & 78.20 & $<10$ & 23.30 & 27.30 & - & 56.30 & 105.00 & 295.00 & - & 9827.0 & $\begin{array}{l}\text { Defew, et al. } \\
\text { (2005) [98] }\end{array}$ \\
\hline Colombia & $\begin{array}{l}\text { Cienaga } \\
\text { Grande }\end{array}$ & 12.60 & 1.92 & 13.20 & 32.50 & & 23.30 & 91.00 & 623.00 & & 15593.0 & $\begin{array}{c}\text { Perdomo, et al. } \\
\text { (1999) [99] }\end{array}$ \\
\hline \multirow{2}{*}{ Brazil } & Jequia & 160.80 & 1.32 & - & - & - & 98.60 & 483.00 & - & - & - & $\begin{array}{l}\text { Kehrig, et al. } \\
\text { (2003) [100] }\end{array}$ \\
\hline & Antonina & - & - & - & - & - & 1.80 & 7.20 & 29.00 & - & 268.0 & $\begin{array}{l}\text { Madi, et al. } \\
\text { (2015) [101] }\end{array}$ \\
\hline \multirow{2}{*}{ Australia } & Hawksbury & 26.40 & - & - & - & - & 18.90 & 94.00 & - & - & - & $\begin{array}{l}\text { MacFarlane, } \\
\text { (2002) [102] }\end{array}$ \\
\hline & Queensland & 36.00 & 0.60 & $1-72$ & 9.00 & - & $1-12$ & $23-56$ & 103.00 & - & 1056.0 & $\begin{array}{c}\text { Preda and Cox } \\
\text { (2002) [103] }\end{array}$ \\
\hline France & Sinnamary & 26.94 & - & 59.80 & 35.20 & - & 17.92 & 164.12 & 539.41 & - & 47245.0 & $\begin{array}{c}\text { Marchand, et al } \\
\text { (2006) [49] }\end{array}$ \\
\hline \multicolumn{2}{|c|}{ Marine Sediments } & $4-17$ & $0.1-0.3$ & $7-13$ & 9.9 & 10.0 & $10-25$ & $7-38$ & 400.0 & - & $9,900-18,000$ & $\begin{array}{l}\text { Buchman, } \\
\text { (2008) [28] }\end{array}$ \\
\hline
\end{tabular}

Table 2: Comparison between the present results of heavy metals levels in mangrove sediments with earlier reported in the other areas from the world.

$\mathrm{ND}=$ Not detected.

This study also confirms that $\mathrm{Pb}$ had a positive correlation with $\mathrm{Mn}(0.686)$ and $\mathrm{Fe}(0.666)$. Co is also widely scattered in the earth's crust [104]. It has positive correlations with $\mathrm{Fe}$ and $\mathrm{Mn}$ was (0.725) and (0.752), respectively. Thus, it is indicated that its occurrence in the surface sediments might be mainly due to natural sources, as reported by $\mathrm{Hu}$, et al. [74].
$\mathrm{Lu}$, et al. reported that Ni showed a positive correlation with $\mathrm{Cu}$ and $\mathrm{Cr}$ [104]. Based on the correlation coefficient, this study also revealed that $\mathrm{Ni}$ has a positive correlation with $\mathrm{Cu}(0.795)$ and $\mathrm{Cr}(0.707)$ in mangrove sediments. This positive correlation indicated that these metals may originate from similar pollution sources, indicating that these heavy metals were probably originated from common sources $[105,106]$. 


\section{Journal of Ecology \& Natural Resources}

\begin{tabular}{|c|c|c|c|c|c|c|c|c|c|c|}
\hline Variable & $\mathbf{P b}$ & $\mathbf{C d}$ & $\mathbf{C r}$ & $\mathbf{N i}$ & $\mathbf{C o}$ & $\mathbf{C u}$ & $\mathbf{Z n}$ & $\mathbf{M n}$ & $\mathbf{M g}$ & $\mathbf{F e}$ \\
\hline $\mathbf{P b}$ & 1.000 & & & & & & & & & \\
\hline $\mathbf{C d}$ & 0.273 & 1.000 & & & & & & & & \\
\hline $\mathbf{C r}$ & 0.665 & 0.265 & 1.000 & & & & & & & \\
\hline $\mathbf{N i}$ & 0.629 & 0.122 & 0.761 & 1.000 & & & & & & \\
\hline $\mathbf{C o}$ & 0.619 & 0.362 & 0.601 & 0.538 & 1.000 & & & & & \\
\hline $\mathbf{C u}$ & 0.683 & 0.141 & 0.707 & 0.795 & 0.598 & 1.000 & & & & \\
\hline $\mathbf{Z n}$ & 0.59 & 0.225 & 0.661 & 0.694 & 0.618 & 0.747 & 1.000 & & & \\
\hline $\mathbf{M n}$ & 0.686 & 0.257 & 0.633 & 0.646 & 0.752 & 0.667 & 0.802 & 1.000 & & \\
\hline $\mathbf{M g}$ & -0.257 & 0.592 & -0.544 & -0.524 & -0.003 & -0.516 & -0.262 & -0.168 & 1.000 & \\
\hline $\mathbf{F e}$ & 0.666 & 0.41 & 0.335 & 0.504 & 0.725 & 0.446 & 0.702 & 0.855 & 0.25 & 1.000 \\
\hline
\end{tabular}

Table 3: Correlation coefficient of heavy metals in mangrove sediments.

Correlation is significant at $(<0.05$ and $<0.001)$. High correlation $(r=0.7-0.9)$.

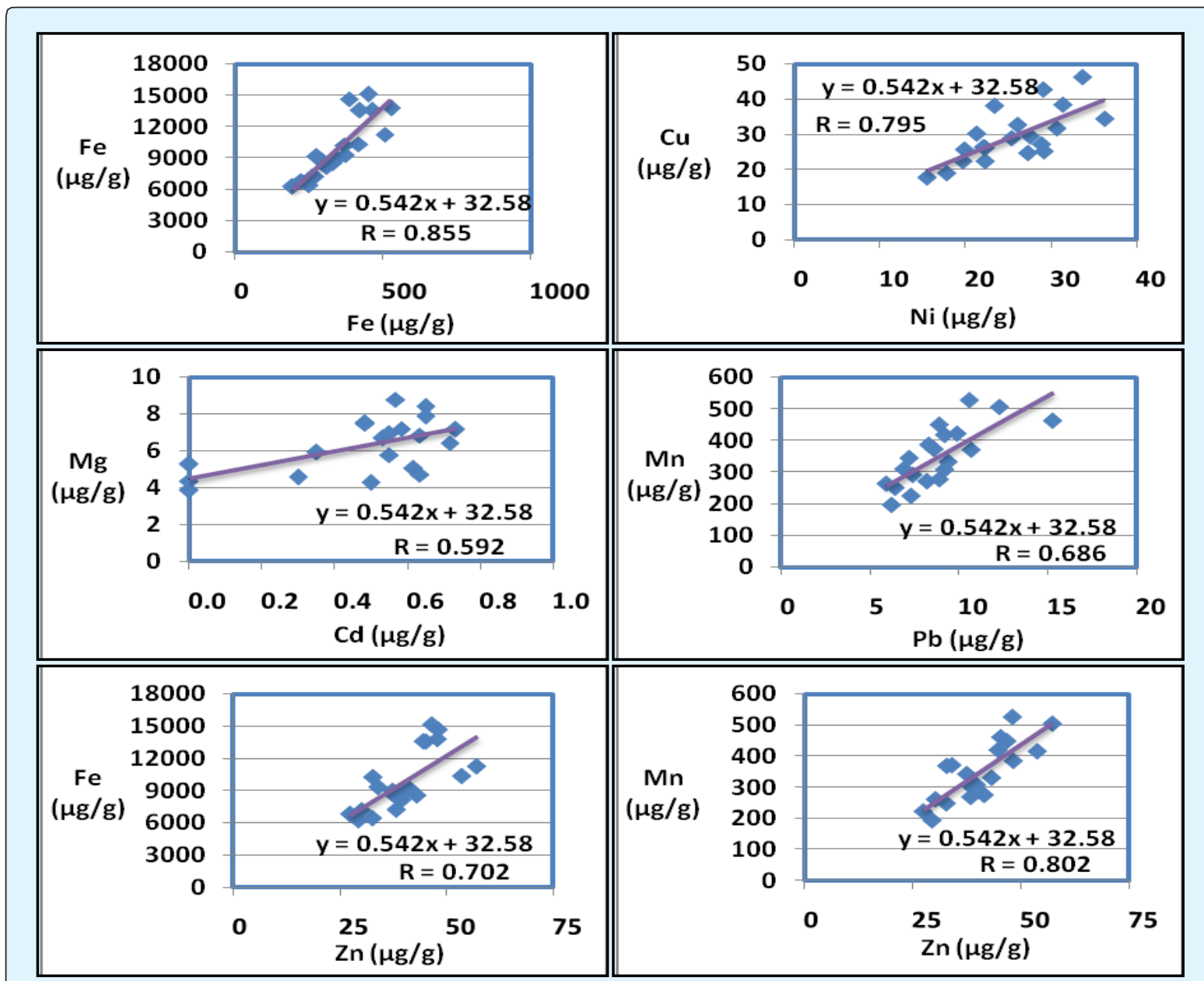

Figure 3: Relationship between selected heavy metals in mangrove sediments.

\section{Conclusion}

This study reveals that heavy metals concentration in mangrove sediments could be arranged in the decreasing order as follows: $\mathrm{Fe}>\mathrm{Mg}>\mathrm{Mn}>\mathrm{Zn}>\mathrm{Cu}>\mathrm{Ni}>\mathrm{Cr}>\mathrm{Pb}>$ $\mathrm{Co}>\mathrm{Cd}$. The investigated sites according to abundance of these metals in mangrove sediments were in the decreasing order of Al-Hodeidah > Ghorairah > Al-Urj > 
Al-Salif > Yakhtol. The levels of heavy metal, which accumulate in mangrove sediments of the study area, differ seasonally and spatially. The higher value of these metals in mangrove sediments were at Al-Hodeidah could be due to increasing anthropogenic activities in the vicinity of this site, whereas at Ghorairah may be attributed to the potential contaminants that carried by water currents coming from the Gulf of Aden, in addition, location of this site near Bab-el-Mandeb Strait. Al-Salif and Yakhtol showed no pollution by these metals, this might be due to limited influence of anthropogenic activities at these two sites. Elevated metals level during spring and summer might be associated with increasing biological activities, terrestrial run off and rainfall during these seasons. The levels of heavy metals in mangrove sediments were comparable with corresponding in other less polluted area of the world. These metals does not exceed TEL and PEL guidelines, except $\mathrm{Cu}$ and $\mathrm{Ni}$, which indicate that it may be cause low harmful biological effects as proposed by $\mathrm{CCME}$. $\mathrm{Cu}, \mathrm{Ni}, \mathrm{Cd}$ and $\mathrm{Mg}$ showed moderately polluted status according to USEPA. The level of these metals below which seriously adverse biological effects except $\mathrm{Cu}$ and $\mathrm{Ni}$ may be cause low harmful biological effects.

The present study considers the recommendation of carrying out continuous monitoring program for the Red Sea coast of Yemen, and that the levels of heavy metals must remain within the prescribed worldwide ratio. Also this study is baseline data toward future ecological study, conservation and management of the resources of these economically important environments in Red Sea Coast of Yemen.

\section{Acknowledgements}

The authors are highly thankful to department of Earth and Environmental Science and Geological Survey Minerals Resources Board, Ministry of oil and Minerals, Yemen for financial support for the project.

\section{References}

1. Sperotto R, Ricachenevsky F, Williams L, Vasconcelos $M$, Menguer $P$ (2014) From soil to seed: micronutrient movement into and within the plant. Front Plant Sci 5: 438-441.

2. Kaewtubtim P, Meeinkuirt W, Seepom S, Pichtel J (2016) Heavy metal phytoremediation potential of plant species in a mangrove ecosystem in Pattani Bay, Thailand. Appl Ecol Environ Res 14(1): 367-382.
3. Harbison P (1986) Mangrove muds - A sink and a source for trace metals. Mar Pollut Bull 17(6): 246250.

4. MacFarlane GR, Koller C, Blomberg S (2007) Accumulation and partitioning of heavy metals in mangroves: A synthesis of field-based studies. Chemosphere 69(9): 1454-1464.

5. Vane $\mathrm{CH}$, Harrison I, Kim A, Moss-Hayes V, Vickers B, et al. (2009) Organic and metal contamination in surface mangrove sediments of South China. Mar Pollut Bull 58(1): 134-144.

6. Al-Hagibi HA (2017) Study of Some Heavy Metals Concentrations in Mangroves Environment - Red Sea Coast of Yemen. Unpublished M.Sc. Thesis, Fac Sci, Sana'a Univ, Yemen, pp: 161.

7. Al-Hagibi HA, Nagi HM, Al-Selwi KM, Al-Shwafi NA (2015) Hydrographical Studies on Mangroves Ecosystem of the Red Sea Coast of Yemen from AlSalif to Bab-el-Mandeb Strait. University of Aden. J natural applied sci 18(2): 383-391.

8. Deborde J, Marchand C, Molnar N, Della Patrona L, Meziane T (2015) Concentrations and fractionation of $\mathrm{C}, \mathrm{N}, \mathrm{P}, \mathrm{Fe}$, and $\mathrm{S}$ in mangrove sediments along an intertidal gradient (New Caledonia). J Mar Sci Eng 3(1): 52-57.

9. Wang Y, Kinraide T, Wang P, Zhou D, Hao X (2013) Modeling rhizotoxicity and uptake of $\mathrm{Zn}$ and Co singly and in binary mixture in wheat in terms of the cell membrane surface electrical potential. Environ Sci Technol 47(6): 2831-2838.

10. Erakhrumen AA (2014) Potentials of Rhizophora racemosa for Bio-Indication and Dendroremediation of Heavy Metal Contamination in A Mangrove Forest, Ondo State, Nigeria. Nigerian J Agric Food Environ 10(4): 1-5.

11. Li J, Liu J, Lin Y, Yan C, Lu H (2016) Fraction distribution and migration of heavy metals in mangrove-sediment system under sulphur and phosphorus amendment. Chem Ecol 32(1): 34-48.

12. Qiu YW, Yu K, Zhang G, Wang WX (2011) Accumulation and partitioning of seven trace metals in mangroves and sediment cores from three Estuarine wetlands of Hainan Island, China. J Hazard Mater 190(1-3): 631-638. 


\section{Journal of Ecology \& Natural Resources}

13. Marchand C, Allenbach M, Lallier-Vergès E (2011) Relationships between heavy metals distribution and Organic matter cycling in mangrove sediments (Conception Bay, New Caledonia). Geoderma 160(34): 444-456.

14. Madkour HA, Mansour AM, Ahmed AN, El-Taher A (2014) Environmental texture and geochemistry of the sediments of a subtropical mangrove ecosystem and surrounding areas, Red Sea coast, Egypt. Arab J Geosci 7(9): 3427-3440.

15. APHA (2005) Standard Methods for the Examination of Water and Wastewater. 21 ${ }^{\text {st }}$ (Edn.), Washington DC, pp: 1200.

16. Perkin-Elmer Corporation (1996) Analytical Methods for Atomic Absorption Spectroscopy. Perkin-Elmer Corporation, US, pp: 310.

17. Nazir R, Khan M, Masab M, Ur Rehman H, Ur Rauf N, et al. (2015) Accumulation of Heavy Metals (Ni, Cu, $\mathrm{Cd}, \mathrm{Cr}, \mathrm{Pb}, \mathrm{Zn}, \mathrm{Fe}$ ) in the soil, water and plants and analysis of physico-chemical parameters of soil and water Collected from Tanda Dam kohat. J Pharmaceut Sci Res 7(3): 89-97.

18. Tsade HK (2016) Atomic Absorption Spectroscopic Determination of Heavy Metal Concentrations in Kulufo River, Arbaminch, Gamo Gofa, Ethiopia. J Environ Analyt Chem 3: 177-180.

19. Panda SS, Chaturvedi N, Dhal N, Rout N (2013) An assessment of heavy metal accumulation in mangrove species of Bhitarkanika, Odisha, India. Res Plant Biol $3(6): 1-5$.

20. Duan JC, Tan JH, Hao J, Wang S, Hao J, et al. (2012) Size distributions and sources of elements in particulate matter at curbside, urban and rural sites in Beijing. J Environ Sci 24(1): 87-94.

21. Moyo M, Amoo S, Ncube B, Ndhlala A, Finnie J, et al. (2013) Phytochemical and antioxidant properties of unconventional leafy vegetables consumed in southern Africa. South African J Botany 84: 65-71.

22. Tirkey A, Shrivastava P, Saxena A (2012) Bioaccumulation of heavy metals in different components of two Lakes ecosystem. Current World Environ 7(2): 293-297.

23. Adelekan BA, Abegunde KD (2011) Heavy Metals Contamination of Soil and Groundwater at
Automobile Mechanic Villages in Ibadan, Nigeria. Int J Phys Sci 6(5): 1045-1058.

24. Awofolu OR, Mbolekwa Z, Mtshemla V, Fatoki OS (2005) Levels of Trace Metals in Water and Sediment from Tyume River and its effects on an irrigated farmland. Water SA 31(1): 87-94.

25. Hardy DH, Myers J, Stokes C (2008) Heavy Metals in North Carolina Soils: Occurrence and Significance. NC Depart Agric, Consum Ser, pp: 1-2.

26. Salminen R, Demetriades A, Reeder $\mathrm{S}$ (2005) Geochemical Atlas of Europe; Part 1Background Information, Methodology and Maps. Geological Survey of Finland, Otamedia Oy, Espoo, pp: 525.

27. Rudnick R, Gao S (2004) Composition of the Continental Crust. In: Holland H, Turekian K (Eds.), Treatise on Geochemistry, Elsevier, 3: 1-64.

28. Buchman MF (2008) Screening Quick Reference Tables, NOAA OR\&R Report 08-1, Seattle WA, Office of Response and Restoration Div, NOAA: 34.

29. USEPA (1998) Guidelines for Ecological Risk Assessment; Risk Assess Forum, U.S. EPA, Washington DC, pp: 188.

30. CCME (2002) Canadian sediment quality guidelines for the protection of aquatic life; Toxaphene, updated in Canadian Environmental Quality Guidelines, 1999. Canadian Council of Ministers of the Environment, Winnipeg, Manitoba, pp: 189.

31. Akan JC, Abdulrahman F, Ogugbuaja V, Ayodele J (2009) Heavy metals and anion levels in some samples of vegetables grown within the vicinity of Challawa Industrial Area, Kano state, Nigeria. Am J Appl Sci 6(3): 534-542.

32. Sarkar S, Favas P, Rakshit D, Satpathy K (2014) Geochemical Speciation and Risk Assessment of Heavy Metals in Soils and Sediments, In: HernandezSoriano MC (Eds.), Environmental Risk Assessment of Soil Contamination, Intech, pp: 723-757.

33. Jain M, Pal M, Gupta P, Gadre R (2007) Effect of cadmium on chlorophyll biosynthesis and enzymes of nitrogen assimilation in greening maize leaf segments: role of 2-oxoglutarate. Indian J Experiment Biol 45(4): 385-389. 
34. Feng $\mathrm{H}$, Jiang $\mathrm{H}$, Gao W, Weinstein $\mathrm{M}$, Zhang $\mathrm{Q}$, et al. (20110 Metal contamination in sediments of the western Bohai Bay and adjacent estuaries, China. J Environ Manag 92(4): 1185-1197.

35. Wuana RA, Okieimen FE (2011) Heavy Metals in Contaminated Soils: A Review of Sources, Chemistry, Risks and Best Available Strategies for Remediation. Communications Soil Sci Plant Analy 42: 111-122.

36. Wu Q, Tam N, Leung J, Zhou X, Fu J, et al. (2014) Ecological risk and pollution history of heavy metals in Nansha mangrove, South China. Ecotoxicol Environ Saf 104: 143-151.

37. ATSDR (2002) Toxicological profile for chromium. Depart Health and Human Services, Public Health Service, Atlanta, Georgia, pp: 502.

38. Bhagure GR, Mirgane SR (2010) Heavy Metals Contaminations in groundwater and soils of Thane Region of Maharashtra, India. Environ Monit Assess 173(1-4): 643-652.

39. De Mora S, Fowler S, Wyse E, Azemard S (2004) Distribution of heavy metals in marine bivalves, fish and coastal sediments in the Gulf and Gulf of Oman. Mar Pollut Bull 49(5-6): 410-424.

40. Rahman M, Fikria A, Kamaruzzaman B, Nik W (2012) Distribution of trace metals in pore water along Terengganu beach. Australian J Basic Appl Sci 6(7): 213-217.

41. GESAMP (IMO/FAO/UNESCO/WMO/WHO/IAEA/UN/UNEP) (1982) The Health of Oceans. Reports and Studies, GESAMP, (15): 108 pp and UNEP Reg Seas Rep Stud (16): 108.

42. Kabata-Pendias A (2001) Trace Elements in Soil and Plants $2^{\text {nd }}($ Edn.), CRC press Inc, Boca Raton, Florida, pp: 489.

43. Prashanth L, Kattapagari K, Chitturi R, Baddam V, Prasad L (2015) A review on role of essential trace elements in health and disease. J Dr NTR Univ Health Sci 4(2): 75-85.

44. Kim GY, Lee JY, Lee JO, Ryu CH, Choi, BT, et al. (2006) Partial characterization and immunostimulatory effect of a novel polysaccharide protein complex extracted from Phellinus linteus. Biosci Biotechnol Biochem 70(5): 1218-1226.
45. Howe JA, Loeppert R, DeRose V, Hunter DB, Bertsch PM (2003) Localization and speciation of chromium in subterranean clover using XRF, XANES, and EPR spectroscopy; Environ Sci Technol 37(18): 40914097.

46. Smith KA, Paterson JE (1990) Manganese and cobalt. In: Alloway BJ (Eds.), Heavy metals Soils. $2^{\text {nd }}$ (Edn.), Blackie Acad Prof, London, pp: 224-244.

47. Callender E (2003) Heavy metals in the environmenthistorical trends. Treatise on Geochem 9: 67-105.

48. Chakraborty P, Ramteke D, Chakraborty S (2015) Geochemical partitioning of $\mathrm{Cu}$ and $\mathrm{Ni}$ in mangrove sediments: relationships with their bioavailability. Mar Pollut Bull 93(1): 194-201.

49. Marchand $C$, Lallier-Vergès $E$, Baltzer $F$, Albéric $P$, Cossa D, et al. (2006) Heavy metals distribution in mangrove sediments along the mobile coastline of French Guiana. Mar Chem 98(1): 1-17.

50. Churong W, Xin R, Wenxiu L, Zhifei H, Chao K, et al. (2013) Adsorption of Zinc and Copper Heavy Metal Ions from Smelting Waste Water using Modified Lava Particles. J Environ Stud 22(6): 1863-1869.

51. Finkelman RB (2005) Sources and health effects of metals and trace elements in our environment: An Overview. In: Moor TA, Black A, Centeno J, Harding J, Trumm DA (Eds.), Metal Contaminants in New Zealand Resolution Press, Christchurch, New Zealand, pp: $25-46$.

52. Hotz C, Lowe NM, Araya M, Brown KH (2003) Assessment of the trace element status of individuals and populations: The example of zinc and copper. J nutrition 133(5): 1563-1560.

53. Rajappa B, Manjappa S, Puttaiah E (2010) Monitoring of Heavy metal in groundwater of Hakinaka TaluK, India. Contemporary Eng Sci 3(4): 183-190.

54. Sarasiab AR, Mirsalari Z, Hosseini M (2014) Distribution and Seasonal Variation of Heavy Metal in Surface Sediments from Arvand River, Persian Gulf. J Mar Sci Res Dev 4(3): 2-6.

55. Mudhoo A, Sharma SK, Garg VK, Tseng CH (2011) Arsenic: an overview of applications, health, and environmental concerns and removal processes. Critical Rev Environ Sci Technol 41(5): 435-519. 


\section{Journal of Ecology \& Natural Resources}

56. Jonathan S, Bawo D, Adejoye D, Briyai O (2009) Studies on biomass production in Auricularia polytricha collected from Wilberforce Island, Bayelsa State, Nigeria. Am J Appl Sci 6(1): 182-186.

57. Sharma Y, Srivastava V, Singh V, Kaul S, Weng C (2004) Nano-adsorbents for the Removal of Metallic Pollutants from Water and Wastewater. Environ Technol 30(6): 583-609.

58. Bradi BH (2005) Heavy Metals in the Environment: Origin, Interaction and Remediation. (Interface Sci Technol), Acad Press, 6: 282.

59. Zhang J, Wang H, Chen G, Li M (2001) Transportation, accumulation and circulation of heavy metals in mangrove in Futian, Shenzhen. Guangzhou Environ Sci 16: 36-39.

60. Lei Y, Korpelainen H, Li C (2007) Physiological and biochemical responses to high $\mathrm{Mn}$ concentrations in two contrasting Populus cathayana populations. Chemosphere 68(4): 686-694.

61. Crossgrove J, Zheng G (2004) Manganese toxicity upon overexposure. NMR Biomed 17(8): 544-553.

62. Kamaruzzaman B, Nurulnadia M, Azhar N, Shahbudin $\mathrm{S}$, Joseph B (2011) Vertical variation of $\mathrm{Pb}, \mathrm{Cu}$ and $\mathrm{Mn}$ in core sediments collected from Tanjung Lumpur mangrove forest, Pahang, Malaysia. Sains Malaysiana 40(8): 827-830.

63. Hronec O, Vilcek J, Toma J, Adamiin P, Huttmanova E (2010) Environmental components quality problem areas in Slovakia, Mendelova Univ, Brno, pp: 225.

64. Vormann J (2003) Magnesium: Nutrition and Metabolism. Molecular aspect Med 24(1-3): 27-37.

65. Rude RK (1998) Magnesium Deficiency: A Cause of Heterogeneous disease in Humans. J Bone Miner Res 13(4): 749-758.

66. Musfirah AH, Jaharah AG (2012) Magnesium and Aluminum Alloys in Automotive Industry. J Appl Sci Res 8(9): 4865-4875.

67. Wedepohl KH (1995) The composition of the continental crust. Geochim Cosmochim Acta 59(7): 1217-1232.

68. Vincoli JW (1997) Risk Management for Hazardous Chemicals. CRC Press Inc., New York, 2: 3136.
69. Beard JL (200) Iron biology in immune function, muscle metabolism and neuronal functioning. J Nutr 131(28-2): 5685-5695.

70. Dallman PR (1986) Biochemical basis for the manifestations of iron deficiency. Annu Rev Nutrition 6: 13-40.

71. Beldi H, Gimbert F, Maas S, Scheifler R, Soltani N (2006) Seasonal variations of $\mathrm{Cd}, \mathrm{Cu}, \mathrm{Pb}$ and $\mathrm{Zn}$ in the edible Mollusc Donax trunculus (Mollusca, Bivalvia) from the gulf of Annaba, Algeria. African J Agric Res 1(4): 85-90.

72. Bhaskaram P (2001) Immunobiology of mild micronutrient deficiencies. Br J Nutr 85(2): 75-80.

73. Zuo Y, Zhang F (2011) Soil and crop management strategies to prevent iron deficiency in crops. Plant Soil 339(1-2): 83-95.

74. Hu D, He J, Lu C, Ren L, Fan Q et al. (2013) Distribution characteristics and potential ecological risk assessment of heavy metals $(\mathrm{Cu}, \mathrm{Pb}, \mathrm{Zn}, \mathrm{Cd})$ in water and sediments from Lake Dalinouer, China. Ecotoxol Environ Saf 93: 135-44.

75. Fang TH, Hong E (1999) Mechanisms influencing the spatial distribution of trace metals in surficial sediments of the south western Taiwan. Mar Pollut Bull 38(11): 1026-1037.

76. Horowitz AJ, Elrick K (1987) The relation of stream sediment surface area, grain size and composition to trace element chemistry. Appl Geochem 2(4): 437451.

77. Ray A, Tripathy S, Patra S, Sarma V (2006) Assessment of Godavari Estuarine mangrove ecosystem through trace metal studies. Environ Int 32(2): 219-223.

78. Tkalin AV (1996) Chlorinated hydrocarbons in coastal bottom sediments of the Japan Sea. Environ Pollut 91(2): 183-185.

79. Presley BJ, Taylor RJ, Boothe PN 1(992) Trace metal concentration in sediments of Eastern Mississippi Bigh. Mar Environ Res 33(4): 267-282.

80. Fergusson JE (1990) The Heavy Elements: Chemistry, Environmental Impact and Health Effects. Pergamon Press, Oxford, England, pp: 614. 


\section{Journal of Ecology \& Natural Resources}

81. Barreiro R, Real C, Carballeira A (1994) Heavy-Metal Horizontal Distribution in Surface Sediments from a Small Estuary (Pontedeume, Spain). Sci Total Environ 154(1): 87-100.

82. Sharma RK, Agarwal M, Marshall FM (2007) Heavy metals contamination of soil and vegetables in suburban areas of Varanasi, India. Ecotoxicol Environ Saf 66(2): 258-266.

83. Abohassan RA (2013) Heavy Metal Pollution in Avicennia marina Mangrove Systems on the Red Sea Coast of Saudi Arabia. JKAU: Meteorol Environ Arid Land Agric Sci 24(1): 35-53.

84. Usman AR, Alkredaa R, Al-Wabel M (2013) Heavy metal contamination in sediments and mangroves from the coast of Red Sea: Avicennia marina as potential metal bioaccumulator. Ecotoxicol Environ Saf 97: 263-270.

85. Dar MA, El-Saharty AA (2006) Recycling and Retention of some Heavy Metals in the Mangrove Sediments, Red Sea, Egypt. Egyptian J Aquatic Res 32(2): 34-47.

86. Shriadah M (1999) Heavy metals in mangrove sediments of the United Arab Emirates shoreline (Arabian Gulf). Water Air Soil Pollut 116(3): 523-534.

87. Einollahipeer F, Khammar S, Sabaghzadeh A (2013) A Study on Heavy Metal Concentration in Sediment and Mangrove (Avicenia marina) Tissues in Qeshm Island, Persian Gulf. J Novel Appl Sci 2(10): 498-504.

88. Parvaresh H, Abedi Z, Farshchi P, Karami M, Khorasani N, et al. (2011) Bioavailability and concentration of heavy metals in the sediments and leaves of grey mangrove, Avicennia marina (Forsk.) Vierh, in SirikAzini Creek, Iran. Biol Trace Elements Res 143(2): 1121-1130.

89. Davari A, Danekar A, Khorasani N, Javanshir A (2012) Determination of heavy metals in mangrove forests of Booshehr. J Environ 38(3): 27-36.

90. Badarudeen A, Sajan K, Srinivas R, Maya K, Padmalal D (2014) Environmental significance of heavy metals in leaves and stems of Karala mangroves, SW coast of India. Ind J Mar Sci 43(6): 1027-1035.

91. Kathiresan K, Saravanakumar K, Mullai M (2014) Bioaccumulation of trace elements by Avicennia marina. J Coast Life Med 2(11): 888-894.
92. Cuong D, Bayen S, Wurl O, Subramanian K, Wong K, et al. (2005) Heavy Metal Contamination in Mangrove Habitats of Singapore. Mar Pollut Bull 50(12): 17321738.

93. Kumar A, Ramanathan A, Prasad M, Datta D, Kumar $M$, et al. (2016) Distribution, enrichment, and potential toxicity of trace metals in the surface sediments of Sundarbans mangrove ecosystem, Bangladesh: a baseline study before Sundarbans oil spill of December, 2014. Environ Sci Pollut Res 23(9): 8985-8999.

94. Awal MA, Hale W, Stern B (2009) Trace Element Concentrations in Mangrove Sediments in the Sundarbans, Bangladesh. Mar Pollut Bull 58(12): 1922-1958.

95. Li L, Ding Z, Liu J (2008) Distribution of heavy metals in surficial sediments from main mangrove wetlands of China and their influence factors. Acta Oceanologica Sinica 30(5): 160-164.

96. Wu Z, Geng J, Huang L (2015) Heavy Metal Contamination in Sediments and Mangroves from Maowei Gulf, South China. Fresen Environ Bull 24: 1091-1097.

97. Yu R, Hu G, Zhang W, Liu B (2015) Accumulation and Transfer of Heavy Metals in the Mangroves from Quanzhou Bay Wetland, SE Coast of China. J Residuals Sci Technol 12(1): 79-83.

98. Defew LH, Mair JM, Guzman HM (2005) An Assessment of Metal Contamination in Mangrove Sediments and Leaves from Punta Mala Bay, Pacific Panama. Mar Pollut Bull 50(5): 547-552.

99. Perdomo L, Ensminger I, Espinos L, Elsters C, Wallner-Kersanach M, et al. (1998) The mangrove ecosystem of the Cie'naga Grande de Santa Marta (Colombia): observations on regeneration and trace metals in sediment. Mar Pollut Bull 37(8-12): 8-12.

100. Kehrig HA, Pinto FN, Moreira I, Malm O (2003) Heavy metals and methylmercury in a tropical coastal estuary and a mangrove in Brazil. Org Geochem 34(5): 661-669.

101. Madi LM, Boeger M, Reissmann C (2015) Distribution of $\mathrm{Cu}, \mathrm{Fe}, \mathrm{Mn}$, and $\mathrm{Zn}$ in Two Mangroves of Southern Brazil. Brazilian Archives Biol Technol 58(6): 970-976. 
102. MacFarlane GR (2002) Leaf biochemical parameters in Avciennia marina (Forsk.) Vierh as potential biomarkers of heavy metals stress in Estuarine ecosystems. Mar Pollut Bull 44(3): 244-256.

103. Preda M, Cox ME (2002) Trace metal occurrence and distribution in sediments and mangroves, Pumicestone region, SE Queensland, Australia. Environ Int 28(5): 433-449.

104. Lu X, Wang L, Li L, Lei K, Huang L, et al. (2010) Multivariate statistical analysis of heavy metals in street dust of Baoji, NW China. J Hazard Mater 173(13): 744-749.
105. Lu A, Wang J, Qin X, Wang K, Han P, et al. (2012) Multivariate and geostatistical analyses of the spatial distribution and origin of heavy metals in the agricultural soils in Shunyi, Beijing, China. Sci Total Environ 425: 66-74.

106. Nava I, Gonçalves J, Nacke H, Guerini V, Schwantes D (2011) Availability of cadmium, lead and chromium toxic heavy metals in soil and soybean leaf tissue fertilized with different sources of NPK+Zn. Ciência e Agrotecnol 35(5): 884-892.

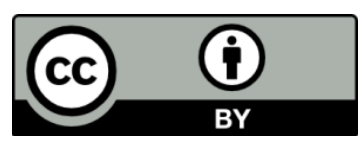

